\title{
The Implications of the EU-Turkey Refugee Agreement on the EU's Role as an International Human Rights Actor
}

\author{
KATIE HELME \\ The University of Melbourne
}

\begin{abstract}
While the European Union (EU) discursively frames itself as a values-driven actor, the recent influx of individuals seeking asylum within its borders problematises this image. The EU-Turkey refugee agreement, signed in March 2016, has been embraced as a mode to offset the burden of mass migration to the EU and to reassert the EU's image as an international human rights actor. This paper contends, however, that the agreement negates the EU's capacity to actively promote human rights norms externally by: 1) compromising on its high standards in order to achieve internal cohesion and redress waning solidarity between member states; 2) transgressing EU and international laws and norms; and 3) relegating the previous approach it has taken to seeking structural reform in Turkey. Ultimately, this paper concludes that the EU's participation in the refugee agreement with Turkey delegitimises the EU as an international human rights actor.
\end{abstract}

Keywords: Common European Asylum System; European Union; Human Rights; Norms; Solidarity; Turkey.

\section{Introduction}

The European Union (EU) frames itself as a values-driven actor, committed to the externalisation of its norms, standards, and principles within its foreign policy, with particular regard to the propagation of human rights doctrines. However, the recent influx of individuals seeking asylum within the EU, stemming from on-going conflicts in its southern neighbourhood, has problematised the EU's collective commitment to its espoused values. In an effort to curtail the movement of 'irregular migrants', the EU completed an agreement with Turkey in March 2016. The agreement binds Turkey to readmit up to 72,000 asylum seekers who have arrived in Greece in return for an equal number to be settled within the EU. Additionally, the EU has committed to accelerate membership negotiations with Turkey, increase the financial support to Turkey's refugee population, and lift visa restrictions for Turkish citizens within the Schengen Area (European Commission 2016a).

This essay will critically assess the implications of the EU-Turkey refugee agreement on the EU's credibility as an international human rights actor. First, it will be argued that the EU has prioritised the securitisation of its external borders over the protection of the individual rights of asylum seekers in order to address the lack of solidarity amongst member states. Second, this essay will show that the agreement is transgressing the EU's own high standards and breaching aspects of international and EU law through rationalising mandatory detention and 'blanket returns' of asylum seekers. Moreover, third, it will contend that, in order to secure the agreement, the EU 
has sacrificed the principled approach that it has previously taken to seeking significant structural reform in Turkey and promoting its normative agenda. Ultimately, it will be concluded that due to the significant concessions on its espoused principles it has had to take in order to secure the refugee agreement with Turkey, the EU is being delegitimised as an international human rights actor, with the ability to credibly 'preach' its values.

\section{Waning Solidarity in EU Asylum Policy}

The EU preaches its own collective and cohesive commitment to high standards within its integrated asylum policy and attempts to export these standards to external actors (Collett 2016; Karageorgiou 2016). However, despite this espoused common value, the adoption of the EU-Turkey refugee agreement reflects a lack of internalised support for human rights principles in asylum policy amongst EU member states. During 2015, the EU received 1.25 million first time applications from asylum seekers requesting international protection, more than doubling the amount it received in 2014 (European Commission 2016b). It can be seen that the rapid increase of asylum seekers has driven the EU to pursue policies to curtail the movement (Crisp 2016). The EUTurkey agreement rationalises the return of potential asylum seekers to Turkey as a 'safe third country' or a 'first country of asylum', in accordance with Articles 35 and 38 of the EU Asylum Procedures Directive (2013/32/EU) (Council of Europe 2016, 3). The return of asylum seekers can be regarded as an attempt to offset the burden and alleviate pressures on EU countries, primarily those that serve as entry points for migrants. In this way, Biondi (2015) contends that through focusing on providing protection in countries of origin or 'safe third countries', the norm of external burden sharing is designed to dissuade potential asylum applicants from entering the EU. As such, the EU has prioritised the securitisation of its external borders over the protection of the individual rights of asylum seekers in response to the waning 'solidarity' between member states (Kneebone 2016, 156; Trauner 2016, 313).

This declining commitment to human rights values within asylum policy is exemplified in Hungary's opposition to the quota of asylum seekers it is required to maintain under the Common European Asylum System (CEAS). In August 2015 Hungary received 46,720 asylum applicants, receiving the largest proportion of all the EU member states despite its relatively small size and population (European Commission 2016b). Under the Dublin Regulation 604/2013 (Dublin III) Hungary was required to offer reception of asylum seekers, process claims, and provide international protection to successful applicants (European Parliament and the Council of the European Union 2013; Barbulescu 2016, 4). However, the lack of internalised commitment to the protection of the rights of asylum seekers and the ontological insecurity caused by mass migration compelled Hungary to close its border with Croatia in September 2015 in an effort to alter the migration flow (Park 2016). Moreover, in response the Hungarian government launched Case C-647/15 against the Council of the European Union within the European Court of Justice, arguing that it was being unfairly overburdened with migrants under the quota system (CURIA 2015). It can be seen that through extending its partnership with Turkey, the EU is attempting to stem the flow of migrants in order to appease the national security interests of its member states. Hence the EU is visibly sacrificing the normative values that it preaches to other external actors in order to achieve internal cohesion.

\section{Transgressing Internal and International Laws}


Furthermore, the EU-Turkey agreement is transgressing aspects of EU and international law through failing to protect the human rights of migrants seeking asylum within its borders. Primarily this has been shown in the contentious legal basis for returning asylum seekers to Turkey. The EU has rationalised the returns by defining Turkey as a 'safe third country' or a 'first country of asylum'. Accordingly, this enabled the EU to return 573 'irregular migrants' to Turkey by October 2016 (European Commission 2016c). However, the EU's return policy involves 'blanket returns' without "spelling out" the refugee protection safeguards in accordance with international law (UNHCR 2016). The agreement also appears to contradict Article 4 of the European Convention of Human Rights, which prohibits the "collective expulsion of aliens". Moreover the 'blanket return' policy appears to contradict Article 43 of the EU Asylum Procedures Directive, which requires the EU to "examine all applications on substance" (European Parliament and the European Council 2013). As such, the inconsistencies between the agreement with Turkey and other aspects of the EU's integrated asylum policy indicate a lack of horizontal coherence. By failing to develop a coherent and cohesive approach to asylum policy the EU is undermining its appearance as an effective international actor.

Moreover, by failing to conform to international laws and standards, the EU is losing support from international and nongovernmental organisations. This is exemplified in the EU's systematic detention of asylum seekers. The EU-Turkey agreement permits the detention of asylum seekers in 'hotspots' on the Greek Islands, supported by Greek law 4375/2016, adopted in April 2016. Article 14 of the law provides for the automatic detention of asylum seekers for between 3-25 days to process claims of new arrivals, and enables the detention of asylum seekers, including those to be returned to Turkey, for up to 18 months (Council of Europe 2016, 6). However, this automatic detention contravenes the principles of the UN Refugee Agency (UNHCR), which maintains a fundamental objection to 'mandatory detention' as "any decision to detain must be based on the individual's particular circumstances" (UNHCR 2012, 16). As such, in objection to the EU-Turkey agreement the UNHCR suspended activities in the Greek Islands on 22 March 2016 (Fleming 2016). Moreover, nongovernmental organisations including the International Rescue Committee (IRC) and Save the Children have withdrawn services out of concern for potential human rights abuses within the detention sites (Collett 2016). It can be seen that the EU derives its legitimacy as an international protector of human rights through support and recognition by international and nongovernmental organisations. Thus, by failing to abide by its own espoused norms and contravening international standards, the EU is being delegitimised as an international human rights actor.

\section{Abandoning the EU's Normative Agenda in Turkey}

Moreover, through engaging in the agreement the EU is sacrificing the principled approach it has taken to seeking structural reform within Turkey. The EU has used its enlargement policy as a way of advancing its normative agenda and exporting its values. However, while the EU has been undertaking membership negotiations with Turkey since 1999, to date only 1 of the 35 negotiated chapters has been completed (Alaranta 2016; Oner 2014). The stalling of negotiations has coincided with a period of stagnation in Turkey's democratic reform process (Aydın-Düzgit \& Kaliber 2016). Alaranta $(2015,10)$ argues that the accession negotiations have been problematised by the "hegemonic discourse of a 'New Turkey" propagated by the ruling Justice and Development Party (AKP) of President Recep Tayyip Erdogan. This discourse has 
reflected a shift away from Europeanisation and democratisation. Due to the lack of conformity to its espoused norms, the EU has criticised Turkey, voicing particular concern for the lack of freedom of press, expression, and assembly, as well as the disproportionate use of force by police against protestors (Aydın-Düzgit \& Kaliber $2016,2)$. This was exemplified in the Gezi Park protests in May 2013, in which Turkish citizens demonstrated against the growing authoritarian nature of the AKP government, with particular emphasis on the freedom of expression. The protests resulted in the death of 5 people, with 8,000 reported as injured (Aydın 2014). In the 2013 Turkey Progress Report, the European Commission condemned the Turkish government's "excessive use of force" and the need for law enforcement to be "brought in line with European standards" to guarantee "respect for human rights and the right to freedom of assembly" (European Commission 2013, 2). It can be seen that the EU has been highly critical of Turkey in the past and has attempted to export its human rights norms.

By engaging in the refugee agreement with Turkey, however, the EU is making concessions on the principled approach it has previously taken to promoting its human rights values in Turkey. The agreement promises to speed-up visa liberalisation for Turkish citizens to access the Schengen Area, although it is yet to grant it. In order to receive visa liberalisation Turkey needs to achieve 72 benchmarks, including document security, migration management, public order and security, fundamental rights, and readmission of irregular migrants (European Commission 2016b). However, little emphasis has been placed on human rights, particularly freedom of expression, as a criterion. Through granting this concession and providing Turkey with a privilege usually reserved for members, the EU is sacrificing a bargaining tool that would aid it in pursuing political reform in Turkey (Alaranta 2016). Verhofstadt (2016) argues that the EU-Turkey agreement diminishes the EU's image as a protector of freedom of speech and freedom of press, and ensures that the EU has "forfeited any right to lecture" Erdogan. However, it is important to note the values that the EU is attempting to export are inherently Eurocentric, and do not necessarily reflect the individual context of Turkey. Nonetheless, through failing to uphold its own principles with regard to the exportation of its values, the EU is undermining its self-professed role as a values-driven actor. In this way, the EU is approaching Turkey as a strategic partner rather than as a potential member, prioritising its own security concerns over seeking political reform (Aydın-Düzgit and Kaliber 2016, 3). Ultimately, it can be seen that the EU's selective pursuit of the exportation of human rights doctrines, as displayed in the agreement with Turkey, is undermining its role as an international human rights actor.

\section{Conclusion}

This essay has critically analysed the implications of the EU-Turkey refugee agreement for the role of the EU as an international human rights actor. First the essay argued that the EU frames itself as a unified, model power, which propagates certain universal values that it is committed to upholding. However, through engaging in the agreement with Turkey the EU is visibly sacrificing the normative values that it preaches to other external actors in order to achieve internal cohesion. Second, this essay contended that the EU has prioritised the securitisation of its external boarders over the individual rights of asylum seekers, rationalising the 'blanket return' and detention of asylum seekers. Accordingly, the EU has lost credibility with international and nongovernmental organisations through transgressing aspects of international and EU law and failing to protect the rights of asylum seekers. Third, this essay showed that 
the EU has made significant concessions on the approach it has traditionally taken to seeking human rights reform in Turkey in order to secure the agreement. Ultimately, it can be concluded that the EU-Turkey refugee agreement is delegitimising the EU as a credible international actor with the capacity to preach normative human rights values.

\section{Bibliography}

Alaranta, T 2015, 'Turkey under the AKP: a critical evaluation from the perspective of Turkey's EU negotiation', The Finnish Institute of International Affairs Working Paper, February.

Alaranta, T 2016, 'The Problematic EU-Turkey refugee deal: the EU downplays its structural foreign policy in order to secure internal unity', The Finnish Institute of International Affairs, December.

Aydın-Düzgit, S \& A Kaliber 2016, 'Encounters with Europe in an Era of Domestic and International Turmoil: Is Turkey a De-Europeanising Candidate Country', South European Society and Politics, vol. 21 no. 1, 1-14.

Aydın, S 2014, 'EU's Response to Gezi Park Protests: A Reflection on EU's Effectiveness', accessed 25 June 2018, http://www.academia.edu/9545999/EUs_Response_to_Gezi_Park_Protests

Babulescu, R 2016, 'Still a Beacon of Human Rights? Considerations on the EU Response to the Refugee Crisis in the Mediterranean', Mediterranean Politics, 1-8.

Biondi, P 2015, 'Human security and external burden-sharing: the European approach to refugee protection between past and present', The International Journal of Human Rights, vol. 20 no. 2, pp. 208-222.

Collett, E 2016, 'The Paradox of the EU-Turkey Refugee Deal', Migration Policy Institution, accessed 25 June 2018, http://www.migrationpolicy.org/news/paradoxeu-turkey-refugee-deal

Council of Europe, The situation of refugees and migrants under the EU-Turkey Agreement of 18 March 2016, Parliamentary Assembly of the Council of Europe, Strasbourg.

Crisp, J 2016, 'Protection and pragmatism: the EU-Turkey refugee deal in historical perspective', Open Democracy, accessed 25 June 2018https://www.opendemocracy.net/openglobalrights/jeff-crisp/protection-andpragmatism-eu-turkey-refugee-deal-in-historical-perspecti

CURIA 2016, 'Hungary vs. the Council of the European Union, Case C-647/15', accessed 25 June 2018,

http://curia.europa.eu/juris/document/document.jsf?text=\&docid=174029\&pageIn $\mathrm{dex}=$ o\&doclang $=\mathrm{EN} \&$ mode $=$ lst $\& \operatorname{dir}=\&$ occ $=$ first $\&$ part $=1 \& \operatorname{cid}=112123$

European Commission 2016a, EU-Turkey Agreement: Questions and Answers, accessed 25 June 2018, http://europa.eu/rapid/press-release_MEMO-16963_en.htm 
European Commission 2016b, 'Asylum quarterly report', accessed 25 June 2018, http://ec.europa.eu/eurostat/statistics-

explained/index.php/Asylum_quarterly_report

European Commission 2016c, Implementing the EU-Turkey Agreement: Questions and Answers, accessed 25 June 2018, http://europa.eu/rapid/press-release_MEMO16-3204_en.htm

European Commission 2013, Turkey's progress on the visa liberalisation roadmap, European Commission, Brussels.

European Parliament and the Council of the European Union 2013, Regulation (EU) no 604/2013 of the European Parliament and of the Council of 26 June 2013, European Parliament and the Council of the European Union, Brussels.

Fleming, M 2016, 'UNHCR redefines role in Greece as EU-Turkey deal comes into effect', The UN Refugee Agency, accessed 25 June 2018, http://www.unhcr.org/56f10do49.html.

Karageorgiou, E 2016, 'Solidarity and sharing in the Common European Asylum System: the case of Syrian refugees', European Politics and Society, vol. 17 no. 2, 196214 .

Kneebone, S 2016, 'Comparative regional protection frameworks for refugees: norms and norm entrepreneurs', The International Journal of Human Rights, vol. 20 no. 2, 153-172.

Oner, S, 'Internal factors in the EU's transformative power over Turkey: the role of Turkish civil society', Southeast European and Black Sea Studies, vol. 14 no. 1, 23-42.

Park, J 2015, 'Europe’s Migration Crisis', Council on Foreign Relations, September.

Trauner, F 2016, 'Asylum Policy: the EU's Crises and the Looming Policy Regime Failure', Journal of European Integration, vol. 38 no. 2, 311-325.

UNHCR 2012, Detention Guidelines, UN Refugee Agency, Geneva.

UNHCR 2016, UNHCR Expresses Concern over EU-Turkey Plan, accessed 25 June 2018, http://www.unhcr.org/en-au/news/latest/2016/3/56dee1546/unhcrexpresses-concern-eu-turkey-plan.html

Verhofstadt, G 2016, 'The Turkey Refugee Deal: Europe Sells Out', Social Europe, accessed 25 June 2018, https://www.socialeurope.eu/2016/o5/the-turkey-refugeedeal-europe-sells-outeurope-sells-out/ 